University of Nebraska - Lincoln

DigitalCommons@University of Nebraska - Lincoln

Papers in the Earth and Atmospheric Sciences Earth and Atmospheric Sciences, Department

1984

\title{
Paleontological Synthesis, Leg 77
}

David K. Watkins

University of Nebraska-Lincoln, dwatkins1@unl.edu

Charles L. McNulty

University of Texas at Arlington

Follow this and additional works at: https://digitalcommons.unl.edu/geosciencefacpub

Part of the Earth Sciences Commons

Watkins, David K. and McNulty, Charles L., "Paleontological Synthesis, Leg 77" (1984). Papers in the Earth and Atmospheric Sciences. 226.

https://digitalcommons.unl.edu/geosciencefacpub/226

This Article is brought to you for free and open access by the Earth and Atmospheric Sciences, Department of at DigitalCommons@University of Nebraska - Lincoln. It has been accepted for inclusion in Papers in the Earth and Atmospheric Sciences by an authorized administrator of DigitalCommons@University of Nebraska - Lincoln. 


\title{
31. PALEONTOLOGICAL SYNTHESIS, LEG $77^{1}$
}

\author{
David K. Watkins, Department of Geology, Florida State University, Tallahassee, Florida \\ and \\ Charles L. McNulty, Department of Geology, University of Texas at Arlington, Arlington, Texas
}

\begin{abstract}
Biostratigraphic age assignment and paleoecological analysis of the sedimentary material recovered on Deep Sea Drilling Project Leg 77 provide a temporal and paleoenvironmental framework for the reconstruction of the Cretaceous and Cenozoic geologic history of the deep southeastern Gulf of Mexico. Planktonic foraminiferal and calcareous nannofossil biostratigraphy, in conjunction with sedimentologic evidence, indicates the sporadic nature of sedimentation during the Turonian through Holocene throughout the study area. This trend is especially well developed within the Upper Cretaceous, which is largely represented only by a thin, condensed section at a single site. The Cenozoic is somewhat better represented, although the thin, unconformity-bound beds characteristic of this interval indicate that sedimentation was still quite sporadic. The record for the Cenomanian and Early Cretaceous is more complete although more variable across the study area. Sites drilled on isolated knolls in the western part of the study area ("basement sites") yield sequences of calcarenites overlain by pelagic sediments. At one site (536), these calcarenites are definitely derived from carbonate platform debris shed into a deeper-water environment. Poor core recovery made it difficult to ascertain whether the calcarenites at the other two basement sites were derived from transported platform debris or in situ outer platform deposition. Two sites drilled on the eastern side of the study area ("basin site") penetrated thick sequences of Cenomanian and Lower Cretaceous hemipelagic deposits. Reworked shallow-water carbonate debris was a consistent and volumetrically important component in these sequences. This fine carbonate debris, probably transported into the basin as distal turbidites, diluted and at times totally overwhelmed the pelagic component of the sediment.
\end{abstract}

\section{INTRODUCTION}

During Leg 77 of the Deep Sea Drilling Project, eight holes were drilled at five sites near the western Straits of Florida in the southeastern Gulf of Mexico (Fig. 1). Sites 535,539 (aborted hole), and 540 are located on the flank of a prominent erosional channel, near the southwestern portion of the Florida Bank. These sites were drilled to investigate the thick sequence of pre-middle Cretaceous sediments that were exposed on the flank of the channel as indicated by seismic evidence. These sites were designated as "basin" sites. Basin Hole 540 ended in the lower Albian, whereas basin Hole 535 reached the upper Berriasian and taken together, these sites yielded a composite section of Cretaceous strata. This composite serves as a record of the late Berriasian through middle Cenomanian history of sedimentary basin fill in this part of the Gulf.

Site 536 is located on the lower flank of the Campeche Escarpment, whereas Sites 537 and 538 are located on isolated submarine knolls. Seismic evidence indicated that Sites 536, 537, and 538 were tilted, uplifted basement blocks with thin sedimentary cover. These three sites were drilled to investigate the nature of the basement rocks in this part of the Gulf and thus were designated "basement" sites. Holes 537 and 538 terminated in igneous and metamorphic rocks of the "transitional" crust suggested by earlier seismic investigations. Site 536

\footnotetext{
1 Buffler, R. T., Schlager, W., et al., Init. Repts. DSDP, 77: Washington (U.S. Govt. Printing Office).
}

ended in dolomite of uncertain (but probably pre-Cretaceous) age.

The biostratigraphic data of Leg 77 is voluminous, complex, and, in part, contradictory. The data for this synthesis are from the following sources:

\begin{tabular}{ll}
$\begin{array}{c}\text { Cenozoic calcareous } \\
\text { nannofossils }\end{array}$ & Lang and Watkins \\
$\begin{array}{c}\text { Cenozoic planktonic } \\
\text { foraminifers }\end{array}$ & Premoli Silva and McNulty \\
$\begin{array}{c}\text { Cretaceous ammonites } \\
\text { Cretaceous benthic } \\
\text { foraminifers }\end{array}$ & Young \\
$\begin{array}{c}\text { Cretaceous calcareous } \\
\text { nannofossils }\end{array}$ & Wliter and Premoli Silva \\
$\begin{array}{c}\text { Cretaceous calpionellids } \\
\text { Cretaceous orbitolinid } \\
\text { foraminifers }\end{array}$ & Premoli Silva and McNulty \\
$\begin{array}{c}\text { Cretaceous ostracodes } \\
\text { (basal Hole 537) }\end{array}$ & Oertli \\
$\begin{array}{c}\text { Cretaceous palynomorphs and Schroeder } \\
\text { Cretaceus palynomorphs } \\
\text { (basal Hole 537) }\end{array}$ & $\begin{array}{l}\text { Riley and Fenton } \\
\text { Tyson }\end{array}$ \\
\hline
\end{tabular}

The data reported by Tyson are presented in site chapter, Site 537 (this volume). All others are reported in specialty chapters of the Biostratigraphic section of this volume.

The sedimentary record encountered across the study area is intermittent and laterally variable, reflecting both the general instability of sedimentation and, in the Cretaceous, the depositional contrast between the basin and basement sites. The combined sedimentary record for the Cenozoic is incomplete, generally consisting of thin beds of pelagic sediment bounded by unconformities. The record for most of the Upper Cretaceous is missing, with only a few thin beds of pelagic and/or volcanogenic, 


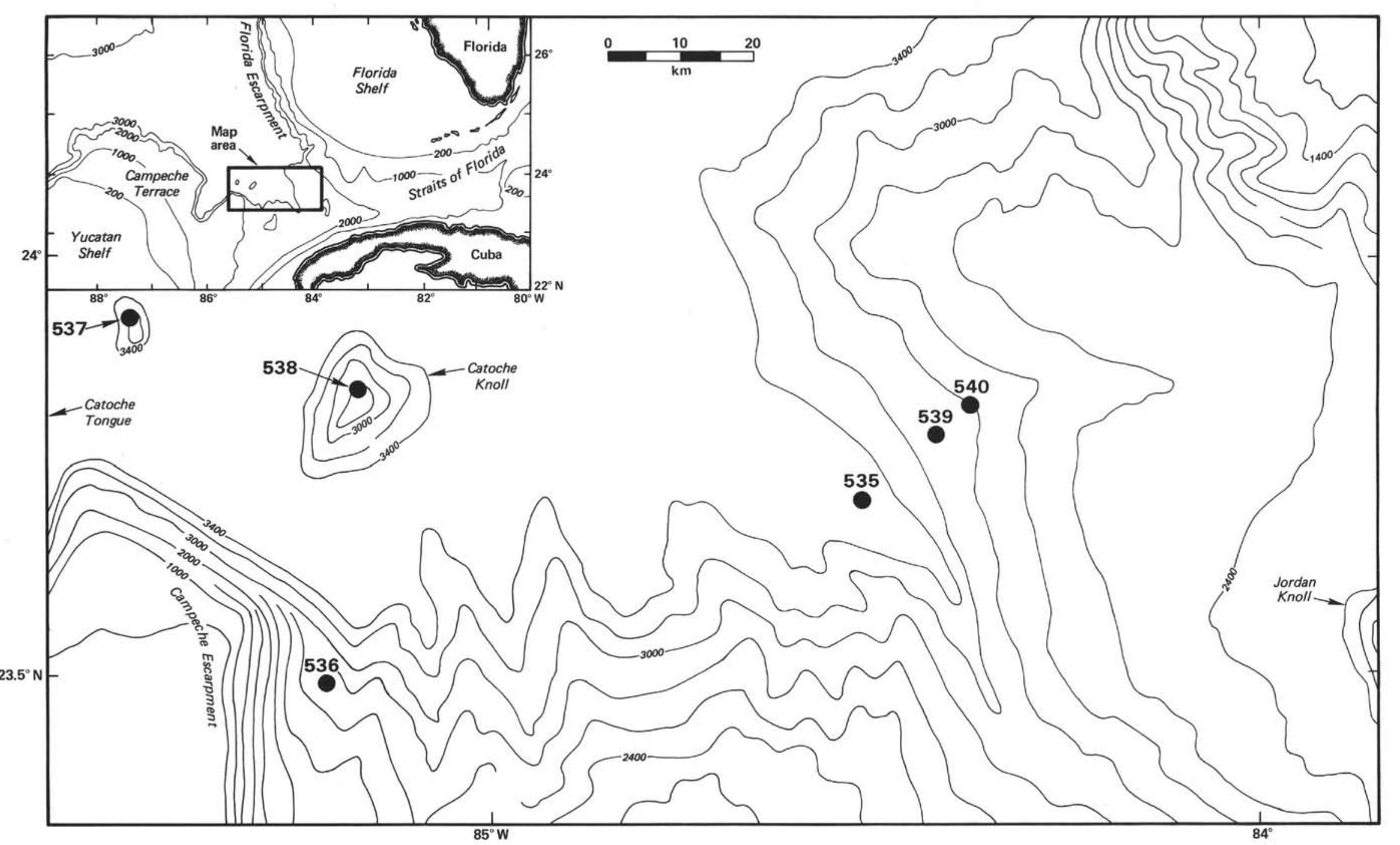

Figure 1. Map of DSDP Leg 77 sites. 
turbiditic sediment apparently preserved. The Lower Cretaceous is short and erratic at the basement Sites 536,537 , and 538 , where very poorly recovered calcarenites $^{2}$ and minor, interbedded lime mudstones and marls lie on transitional crust or (at Site 536) significantly older dolomite. The Lower Cretaceous is quite thick at the basin sites, but the record is still somewhat discontinuous, and the biostratigraphic data are sporadic, occasionally contradictory, and complicated by displacement and reworking.

The specific age assignments for the sedimentary material from Leg 77 are summarized in Figures 2 to 5 . These assignments were made using all the available biostratigraphic data for a given interval. In general, there was agreement between all fossil groups on the age assignment for a specific interval. The use of more than one fossil group allowed us to subdivide the Leg 77 material with a high degree of biostratigraphic resolution. Occasionally, slight differences in the age assignment of a specific interval were encountered. Detailed examination of the samples often revealed some fossil reworking which resolved the apparent conflict. In other cases, however, reworking was not evident. In these few cases, the interval was assigned to the youngest age reported. In all but one case, this potential error involved less than 2 million years and in fact, may, have resulted from errors in calibration of the relative biostratigraphic time scales to the absolute time scale. The one significant exception was in the interval from Core 535-17, CC through 535-45. This exceptional situation is discussed at length later in this paper.

\section{CENOZOIC}

Cenozoic material was recovered from all holes drilled during Leg 77. Cenozoic sediment consists mostly of pelagic, calcareous ooze and chalk, although a significant section of fine-grained clastic material was drilled at Site 535. The Cenozoic sedimentary record is generally thin, laterally variable, and temporally varied and sporadic. Temporal assignments for the Cenozoic are based upon planktonic foraminifers and calcareous nannofossils. Most of the assemblages have tropical affinities, with the exception of those from short intervals in the upper Pleistocene of Sites 535 and 539.

The Neogene is only sparsely represented in the Leg 77 material (Fig. 2). Upper Pleistocene and Holocene sediments were recovered from all sites. At Site 535, 17 cores of upper Pleistocene and Holocene distal fan muds and mudstones were recovered. These sediments contain common reworked microfossils derived from Upper Cretaceous and, to a lesser extent, Neogene strata. This thick sequence of distal fan deposits lies directly upon Cretaceous limestones, indicating a significant pre-Pleistocene unconformity. The Quaternary at all of the other sites consists of thin, pelagic, calcareous biogenic de-

\footnotetext{
2 This term is used here for the skeletal limestones and oolitic-oncolitic limestones of Sites 536 and $537 / 538$, respectively. Texturally, they include grainstone, packstone, and minor amounts of wackestone, according to the Dunham 1962 classification (see Introduction and Explanatory Notes chapter, this volume). Grain size is predominantly sand-size, although coarser material does occur.
}

posits lying unconformably on older Neogene strata. The trend towards thin beds bounded by unconformities is evident throughout the rest of the Neogene and, to a lesser extent, the Paleogene of the holes drilled during Leg 77.

The Pliocene is represented by sediments in four of the eight holes drilled. In all cases, the Pliocene is less than $12 \mathrm{~m}$ thick and is usually substantially thinner. The late Pliocene is restricted to thin beds in Holes 538 and 539. The latter hole was terminated at this stratigraphic level. The early Pliocene is represented by thin, unconformity-bound intervals in Holes 536, 537, and 538. Thin beds of upper Miocene occur in the material recovered from Holes 536, 539A, and 540. Most of the upper Miocene is present at Site 540, although the uppermost Miocene is apparently missing. The middle Miocene occurs in Holes 536, 538A, and 540 as thin beds bounded by unconformities. No lower Miocene sediment was recovered on Leg 77.

The Paleogene is better represented than the Neogene in the Leg 77 material (Fig. 3). Seven of the eight holes drilled penetrated the Paleogene (or below), although two holes (538 and 539A) were terminated in the upper Oligocene. Of all of the epochs of the Cenozoic, the Oligocene is by far the best represented in the Leg 77 material. Five of the seven holes that penetrated to or through the Paleogene contain uppermost Oligocene sediments. In two of these holes (536 and 537), this was the only Oligocene sediment recovered by drilling operations. The latest Oligocene was obviously a time of sediment deposition over the entire study area. This is in marked contrast to the overlying lower Miocene which, apparently, is not preserved anywhere in this part of the Gulf. Long, nearly complete sequences of Oligocene sediments were recovered from Holes 538A and 540. This is a significant departure from the thin, unconformity-bound beds that are more characteristic of Cenozoic sedimentation here. The preservation of these long, apparently continuous Oligocene sections is even more interesting because of the differing site topography. Hole 538A was drilled on top of Catoche Knoll, which is exposed to current activity and susceptible to erosion. Site 540, on the other hand, was on a more protected upper slope of an erosional channel at the western end of the Florida Straits. In both Hole 538A and 540, the entire upper Oliogocene and most of the lower Oligocene is represented. The lowermost Oligocene is absent in Hole 538A and, probably also absent in Hole 540. Lower Oligocene sediments from Site 540 contain an abnormally high percentage of braarudosphaerids and, to a lesser extent, holococcoliths. This indicates unusual and, perhaps, restricted oceanographic conditions for the Gulf during this time. Cyclic cooling in the Oligocene is suggested by variation in dissolution of calcareous microfossils, the abundance and size distributions of planktonic foraminifers (Premoli Silva and McNulty, this volume), and, to a lesser extent, by the oxygen isotope record (Belanger and Matthews, this volume).

The Eocene in this area was similar in depositional style to the Neogene, with thin, unconformity-bound beds of disparate age. Upper Eocene sediments were recov- 


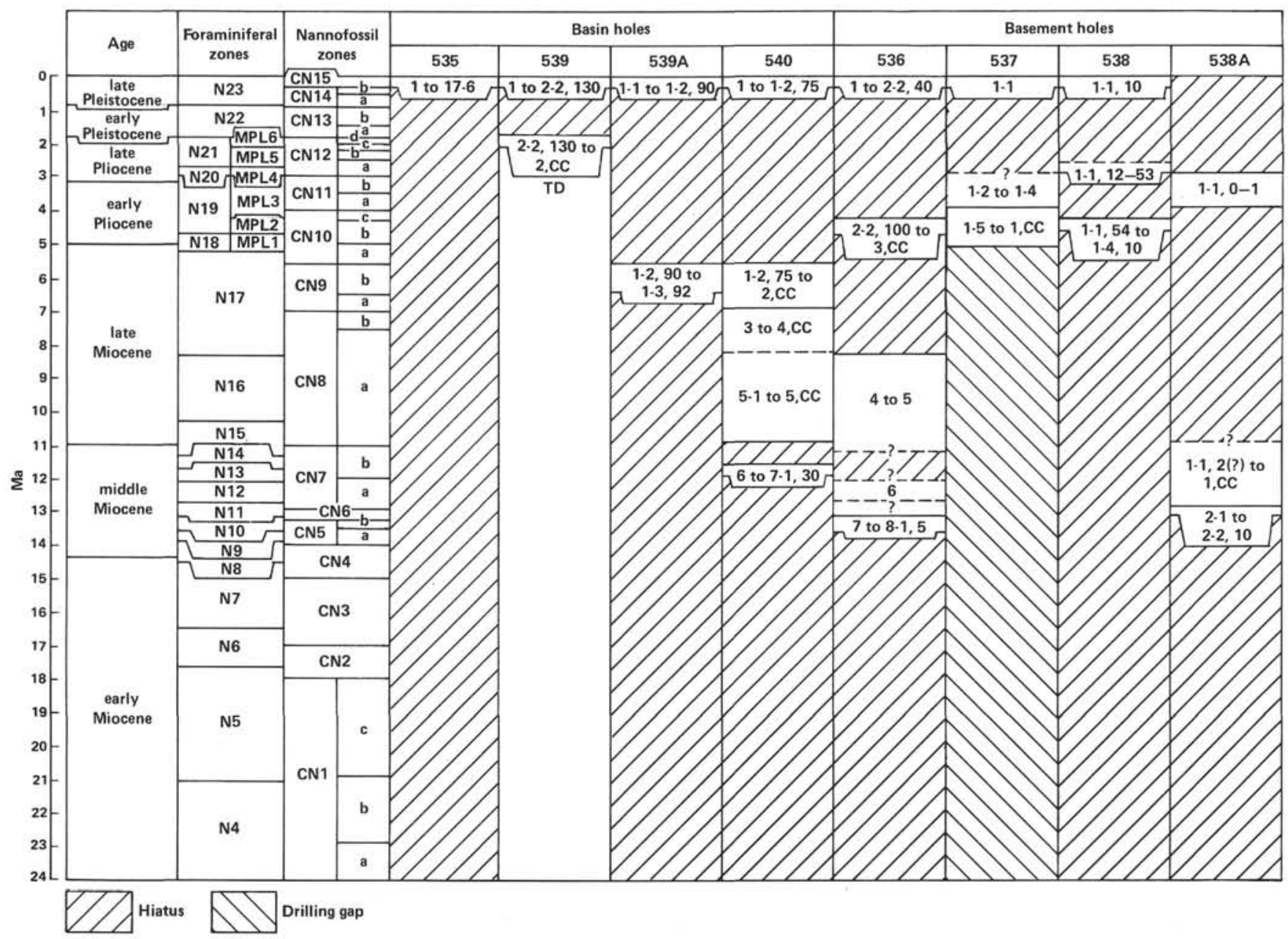

Figure 2. Age assignments for Neogene material from DSDP Leg 77. Assignments are based upon planktonic foraminiferal and calcareous nannofossil biostratigraphy. Locations in holes are expressed as core, core-section, or core-section, depth in section in $\mathrm{cm}$. TD = total depth.

ered from Holes 538A and 540. Another time of widespread sedimentation and sediment preservation occurred near the early/middle Eocene boundary. Four of the five holes that penetrated through the Eocene contain deposits of lower/middle Eocene sediment. These sediments have a higher biogenic silica content than any other deposited during the Cenozoic in this region. This high silica content indicates that the oceanographic conditions responsible for the deposition of Horizon $\mathbf{A}$ in the North Atlantic were at least partially operative in this part of the Gulf of Mexico. Major slumping, perhaps related to tectonic activity, occurred during this time at Site 538. Hole 538A contains more than $5 \mathrm{~m}$ of Paleocene sediment intercalated between early to middle Eocene sediment, indicating detachment and downslope movement of this block during this part of the Eocene.

The late Paleocene was also a time of widespread sedimentation and sediment preservation in the study area. Four of the five holes that penetrated the Paleocene contain upper Paleocene sediment. At Site 540, approximately $2 \mathrm{~m}$ of upper Paleocene chalk is underlain by a complex sequence of turbiditic sediments including apparent hardgrounds. The top of this sequence (540-30-2 through $540-30, \mathrm{CC}$ ) is a graded sandstone-conglomerate unit of late Paleocene age. This is underlain by a sequence of black, pebbly mudstones with some interbedded chalks. The black pebbly mudstones throughout the sequence contain Albian microfossil assemblages, indicating the age of the sediment being reworked and mobilized. The chalk beds contain upper Maestrichtian assemblages in the interval from Core 540-31 through 540-32-1, $18 \mathrm{~cm}$. Below this sequence, the rest of the unit $(540-32-1,18 \mathrm{~cm}$ through 540-36) contains chalk beds (concentrated near the top of the interval) that contain middle Cenomanian microfossil assemblages. The paleontologic evidence suggests that the sediment mobilized during the initial Cenomanian episode was subsequently remobilized during the late Maestrichtian and, to a lesser extent, during the late Paleocene.

\section{CRETACEOUS/TERTIARY BOUNDARY}

An unconformity representing a considerable hiatus in the sedimentary record separates the Cretaceous from the overlying Tertiary at most of the Leg 77 sites. A nearly complete basal Paleocene through uppermost(?) Maestrichtian sequence was recovered in the interval from $536-9-3,18 \mathrm{~cm}$ to $536-9, \mathrm{CC}$. The Maestrichtian is poorly developed, however, and contains reworked microfossils from older Cretaceous strata. 
PALEONTOLOGICAL SYNTHESIS

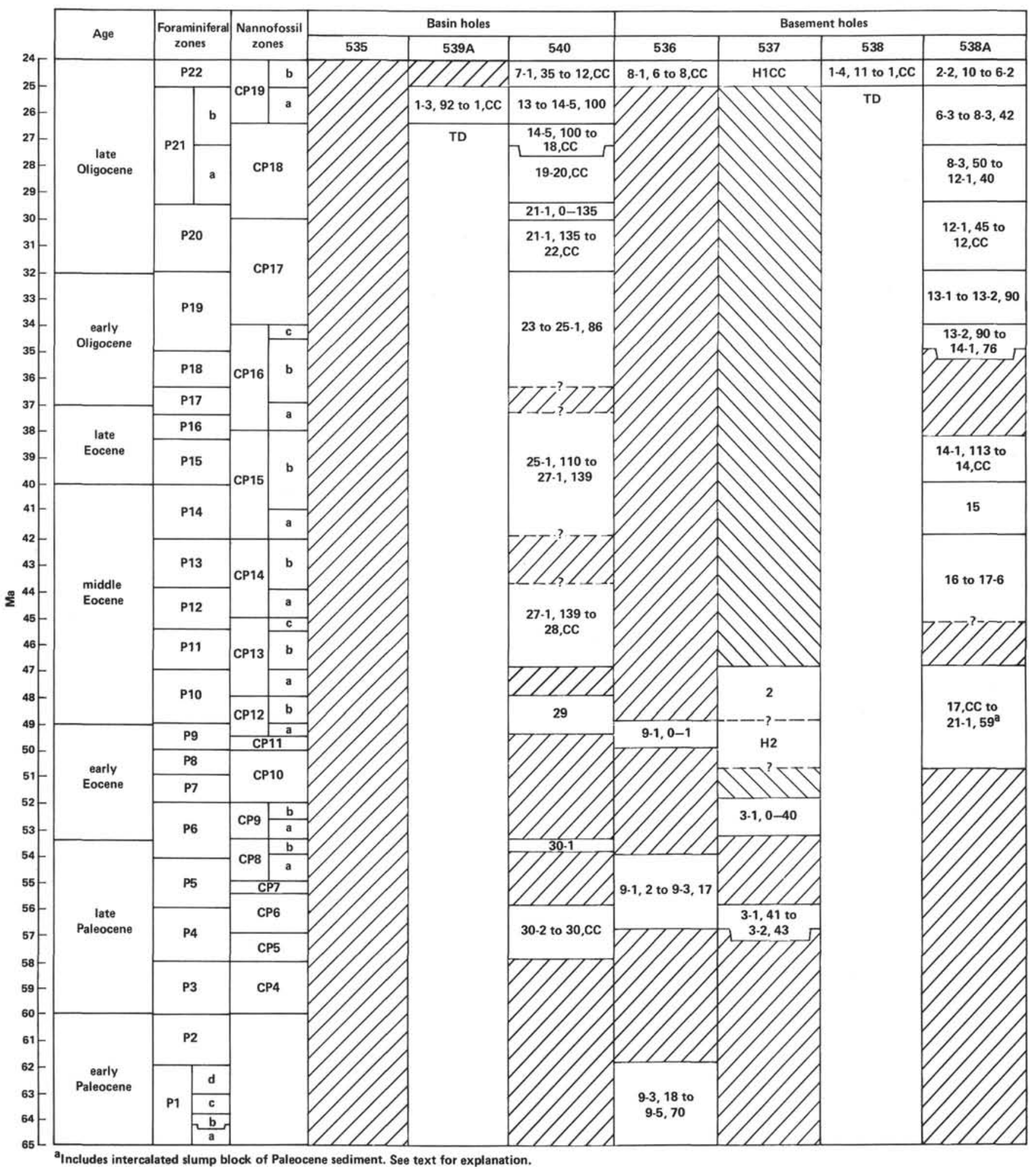

Figure 3. Age assignments for Paleogene material from DSDP Leg 77. Assignments are based upon planktonic foraminiferal and calcareous nannofossil biostratigraphy. Locations in holes are expressed as in Figure 2; see Figure 2 for symbols.

Lower Paleocene planktonic foraminiferal faunas are abundant, diverse, and well preserved at the top of the interval from 536-9-3, $18 \mathrm{~cm}$ through 536-9-5, $69 \mathrm{~cm}$, but deteriorate at the bottom of the interval. The following foraminiferal subzones have been recognized:

$\begin{array}{cr}\begin{array}{c}\text { Morozovella trinidadensis } \\ \text { (P1d) }\end{array} & 536-9-3,18 \mathrm{~cm} \text { to } \\ \text { Subbotina pseudobulloides } & 536-9-4,80 \mathrm{~cm} \\ \text { (P1c-P1a) } & 536-9-4,81 \mathrm{~cm} \text { to } \\ \text { "Globigerina" eugubina } & 536-9-5,51,40 \mathrm{~cm} \\ & 536-9-5,69 \mathrm{~cm}\end{array}$


Foraminiferal preservation deteriorates rapidly in the Maestrichtian (536-9-5, $70 \mathrm{~cm}$ through 536-9, CC) along with the change from chalk to coarse turbiditic siltstone and silty chalk. Even in the chalk, diagnostic globotruncanids are missing, presumably from dissolution. Significant guembelinids (e.g., Racemiguembelina fructicosa) indicate correlation with the Abathomphalus mayaroensis Zone of the upper Maestrichtian.

Lower Paleocene calcareous nannofossil assemblages are rich, diverse, and generally well preserved at the top of this interval. The preservational characteristics of the nannofossils parallel those for the planktonic foraminifers, with increasingly poor preservation as the Cretaceous/Tertiary boundary is approached. Samples from the interval from 536-9-5, 50-70 cm exhibit a marked increase in secondary alteration of these Zygodiscus sigmoides Zone assemblages. In addition, the relative abundance of braarudosphaerids and, to a lesser extent, thoracosphaerids, increases substantially as the boundary is approached from above. A concomitant increase in the abundance of euhedral to subhedral dolomite crystals was also observed in microfossil preparations. These features, coupled with the burrowed nature of the Cretaceous/Tertiary boundary at 536-9-5, $70 \mathrm{~cm}$, indicates intense dissolution during the onset of Paleocene sedimentation and a gradual decrease in secondary alteration upwards from the boundary to about $536-9-5,30 \mathrm{~cm}$. Nannofossil preservation is also poor below the boundary. These assemblages are generally sparse and contain nannofossils reworked from older Cretaceous sediments. The presence of rare Micula prinsii in some samples indicates a latest Maestrichtian age. The consistent occurrence of Broinsonia parca, however, denotes reworked Campanian in the assemblages. In addition, an early(?) Cretaceous contribution to the sediment is suggested by heavily overgrown Nannoconus sp. similar to Nannoconus kamptneri. Thus, the Cretaceous/Tertiary boundary is apparently preserved in the sedimentary record at Site 536, although the nature of the preservation excludes this locality from consideration for detailed study by investigators of the Cretaceous/Tertiary boundary "problem."

\section{UPPER CRETACEOUS}

The Upper Cretaceous is poorly represented in the Leg 77 material (Fig. 4). Thin chalk or turbiditic chalk of varied Maestrichtian age occurs at all holes that penetrated the Cretaceous except at Site 535, where Pleistocene lies directly upon Albian (possibly Cenomanian, see below). The upper Cenomanian through Campanian is absent, except for a few meters of chalk in Hole 538A. The lower and middle Cenomanian is represented by approximately $70 \mathrm{~m}$ of volcanogenic turbidite and laminated limestone at Site 540 .

There are at least two depositional episodes recorded from the Maestrichtian. Volcanoclastic and/or turbiditic sediments from Holes 536 and 540 contain rare late Maestrichtian microfossils mixed with more abundant, reworked older Cretaceous forms. Similar sediments occur in a $23 \mathrm{~cm}$ bed at Site $537(537-3-2,20-43 \mathrm{~cm})$, but only early Maestrichtian and older Cretaceous planktonic foraminifers were observed. These specimens were re- covered only from the base of this bed and may have been reworked from underlying sediments. Lower Maestrichtian chalks were recovered from Hole 538A. One planktonic foraminiferal zone (Globotruncana tricarinata) and two nannofossil zones (Reinhardtites levis and Tranolithus phacelosus) are present, although a minor unconformity may be present in this thin sequence.

The condensed sequence in Hole 538A continues downward with thin, unconformity-bound beds of Campanian and Santonian. The biostratigraphy of this interval is still uncertain and largely controlled by sample distribution. At present, it is known that at least three planktonic foraminiferal zones (G. elevata, Dicarinella asymmetrica, and $D$. concavata) and two nannofossil zones (Ceratolithoides aculeus and Reinhardtites anthophorus) are represented in this thin $(\sim 130 \mathrm{~cm})$ interval. This condensed sequence is the only record of post-Cenomanian, pre-Maestrichtian Cretaceous history recovered from the study area. No upper Cenomanian through Coniacian sediments are present in the Leg 77 material.

The Cenomanian is represented by sediments at Site 540 and, possibly, at Site 535 (Fig. 5). The Cenomanian at Site 540 consists of a turbiditic pebbly mudstone and chalk sequence (lower to middle Cenomanian) underlain by a laminated limestone sequence (lower Cenomanian) that continues down into the Albian. At Site 535, the interval from Core 535-17, CC through Core 535-45 has been questionably assigned to the Cenomanian (by ammonites) and to the Albian (by planktonic foraminifers, calcareous nannofossils, and palynomorphs). The problems in the age assignment of this sequence are discussed later in this paper.

\section{LOWER CRETACEOUS}

The nature of the sedimentary record is quite different at the basin sites and the basement sites. The basin sites yielded thick sections of more or less cyclic, pelagic carbonates with varying amounts of reworked, platformderived, biogenic carbonate debris. The Lower Cretaceous of the basement sites is typically thin and dominated by coarse calcarenites composed of carbonate shelf debris. With one exception, sedimentation was nearly continuous at the basin sites, whereas it was quite sporadic at the basement sites. Because of the marked contrast between the nature of the sedimentary record at the basin and basement sites, they are discussed separately below. Age assignments for these Lower Cretaceous strata are summarized in Figure 5.

\section{Basement Sites}

The Lower Cretaceous of the basement sites is predominantly composed of skeletal calcarenites with occasional interbeds of pelagic limestone. The interpretation of the paleontological and sedimentological records of the basement sites is greatly hampered by the very poor recovery that was characteristic of these intervals. In addition, the predominance of coarse calcarenites of platform-derived skeletal material was not conducive to the preservation of good pelagic faunas and floras. This is especially true for nannofloras, which, with one exception, were either never present or subsequently destroyed 


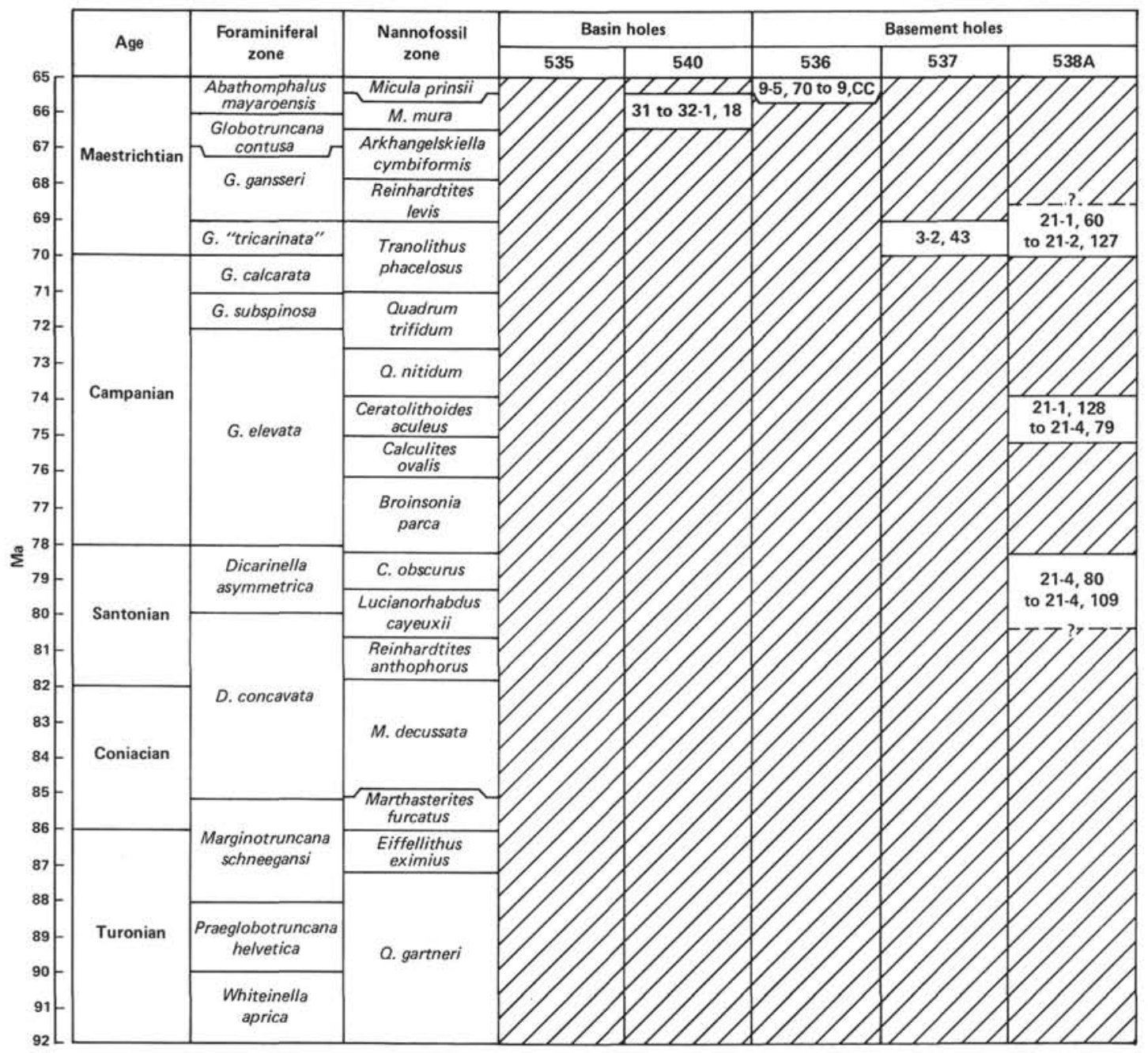

Figure 4. Age assignments for Turonian through Maestrichtian material from DSDP Leg 77. Age assignments are based upon planktonic foraminiferal and calcareous nannofossil biostratigraphy. Locations in holes are expressed as in Figure 2; see Figure 2 for symbols.

by diagenesis. Despite these problems, however, a sufficient amount of biostratigraphic data were derived from the thin section study of planktonic foraminifers and calpionellids to allow the following conclusions to be made.

At Sites 537 and 538, thin sequences of pelagic sediments were preserved above the calcarenite intervals. These pelagic sequences are complex in nature, with several hardgrounds evident at each one. Thin beds of nannofossil chalk of widely varied age (early Aptian, Hole 537; latest Albian, Hole 538A) are present in these sequences. For a more detailed account of the complex nature of these intervals, see Premoli Silva and McNulty (this volume).

The dominant lithology of the Lower Cretaceous at the basement sites consists of coarse calcarenites with interbedded pelagic limestones. Petrographic and paleontologic examination of the calcarenite sequences indicates that those at Site 536 are quite different from those at Sites 537 and 538. The calcarenites at Site 536 are dominated by rudistid and coral debris, whereas the calcarenites at Sites 537 and 538 are predominantly com- posed of oncolites, peloids, and, at Hole 538A, oolites. In addition, the pelagic limestone interbeds are more common in material from Site 536 than at the other two sites. Biostratigraphically, it appears that the calcarenite sequences at Sites 537 and 538 are approximately of equal age (Berriasian to Valanginian) and much older than the calcarenite sequence at Site 536 (Aptian to Albian). The biostratigraphic evidence on which these conclusions are made, however, is far from ideal.

Planktonic foraminifers occur rarely in the calcarenites. Most of the few zonal assignments were derived from the infrequent interbedded pelagic lime mudstones (site chapter, Site 536, this volume) or from the sparse planktonic specimens in the calcarenite matrix (site chapters, Sites 537 and 538, this volume). Some of the shelfal benthic foraminiferal bioclasts (e.g., trocholines) of the calcarenites were also helpful (Sliter and Premoli Silva, this volume). Calpionellids are rare to uncommon in the calcarenite matrix in the lower parts of Holes 537 and 538A. Most of these belong to Calpionellid Zone D, but a few contradictions in specific ranges and the occur- 


\section{K. WATKINS, C. L. MCNULTY}

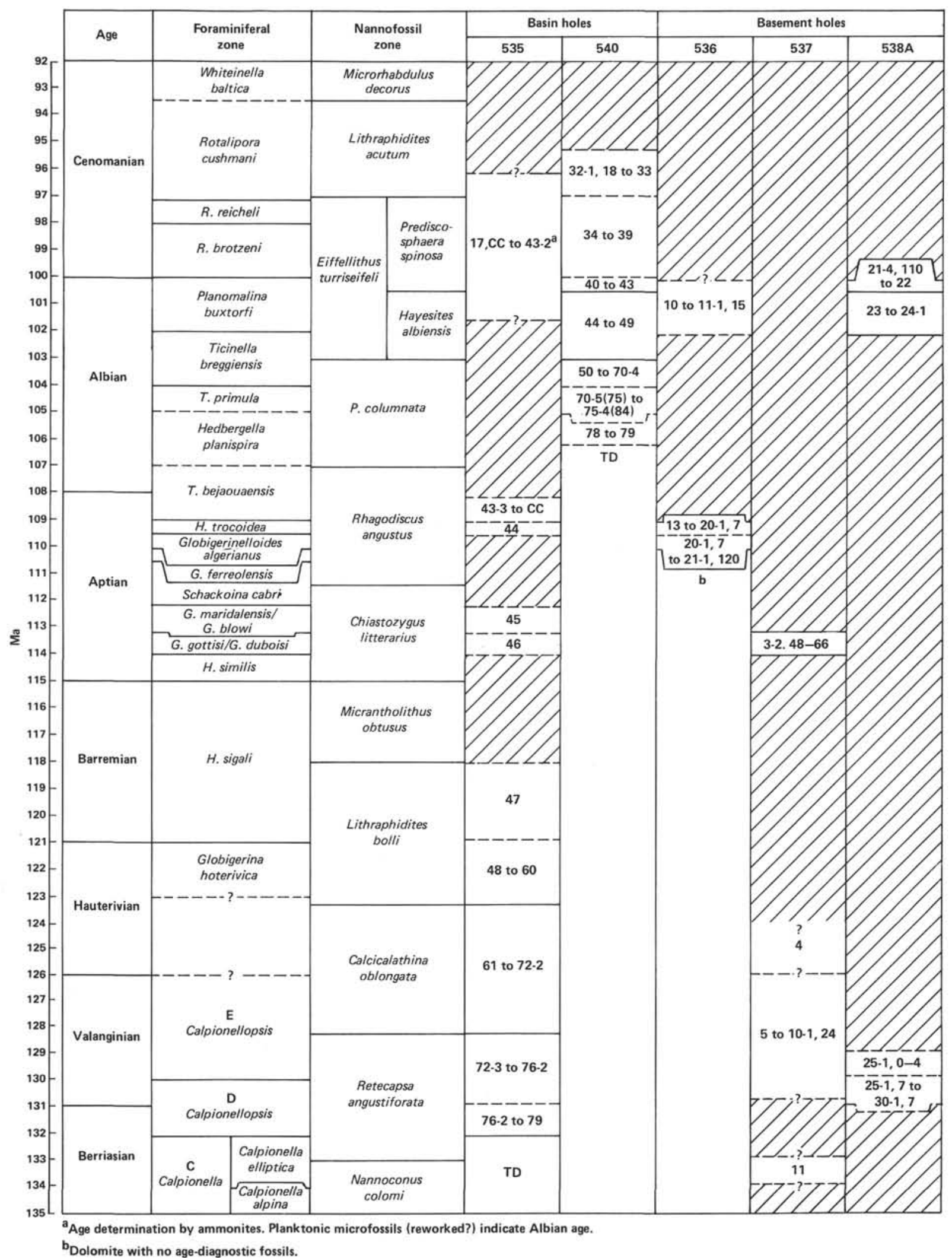

Figure 5. Age assignments for Berriasian through Cenomanian material from DSDP Leg 77. Age assignments for most intervals based upon planktonic foraminiferal and calcareous nannofossil biostratigraphy. Age assignments for sediment at the base of Hole 537 based upon ostracodes and palynology. Age assignments for material from Site 535 based upon planktonic foraminifers, calcareous nannofossils, palynomorphs, and ammonites (see text). Locations in holes are expressed as in Figure 2; see Figure 2 for symbols. 
rence of rare globuligerinids and trocholines suggest reworking and later, as opposed to earlier, Neocomian for the beds in which they occur in Hole 537.

Despite the poor biostratigraphic control available for the interpretation of these calcarenite sequences, it is obvious that those at Sites 537 and 538 are closely related to one another and differ significantly from the sequence at Site 536. There is general agreement that the calcarenites at Site 536 are the result of downslope reworking of shallow water platform debris (probably from Campeche Bank) into the basin. The origin of the calcarenites in Holes 537 and 538A, however, is less certain. The poor quality of the data on the calcarenite sequences in these two holes, largely the result of the particularly poor core recoveries for these intervals, has made it impossible to definitively answer the question of the origin of these sediments. Two possibilities have been proposed. The first is that the skeletal grains have been transported to the sites from shallow water platforms. This possibility would more easily explain the occurrence of calpionellids in the calcarenite sequences. The second possibility is that the calcarenites are in situ deposits of outer or marginal platform type, in which the occurrence of calpionellids is a problem.

The latter explanation is strengthened by examination of the sediments lying below the grainstones at Site 537 . Here, reddish, conglomeratic, arkosic sandstone overlies Lower Paleozoic metamorphic and igneous rocks. This arkosic sandstone is, in turn, overlain by dolomitic marls containing plant and coal fragments (site chapter, Site 537, this volume). This sequence has been interpreted as a transgressive sequence from continental to estuarine to shallow marine(?) sedimentation. Ostracodes from this sequence indicate an earliest Cretaceous age (Oertli, this volume), as do palynomorphs (Tyson, site chapter, Site 537, this volume).

\section{Basin Sites}

Two holes (535 and 540) penetrated the Lower Cretaceous of the deep Gulf of Mexico basin. Both holes (designated "basin holes") were drilled in the upper flank of a prominent erosional channel at the western end of the Straits of Florida. Seismic evidence indicated that a thick sequence of sedimentary rocks, lying stratigraphically below the horizon MCU, was within the reach of the drill string of the Glomar Challenger. The sites were situated so that one hole (535) would penetrate the Lower Cretaceous sequence at about the stratigraphic horizon at which the other hole (540) terminated. Thus, these two holes yielded a composite section that spans much of the Lower Cretaceous sequence.

Basin Site 540 was drilled through approximately $380 \mathrm{~m}$ of Lower Cretaceous limestone and marly limestone. Three lithologic units have been recognized within this interval: an upper unit of limestones and marly limestones with strongly expressed alternations between light and dark lithotypes; a middle unit of limestones with only weakly expressed color alterations; and a lower unit of limestones with a significant component of skeletal limestone. The lithotypes present strongly control the nature of the preservation of the calcareous microfossils in the units.

The upper unit (Cores 540-37 through 540-53) is characterized by strongly developed cyclicity between light-colored bioturbated and/or laminated limestones and dark limestones and/or marly limestones. Calcareous microfossil preservation is generally poor in the lighter limestones. The darker, more clay-rich limestones and especially the marly limestones have significantly better microfossil preservation. Assemblages from these darker horizons allow division of this unit into a regular progression of biozones that span the late Albian through the early Cenomanian.

In the middle lithologic unit of this sequence (Core 540-54 through 540-76), higher rates of the influx of carbonate shelf debris masked the cyclical nature of pelagic sedimentation, so that the color alterations are only weakly expressed. In general, these limestones have higher carbonate contents and a concomitantly poorer microfossil record. Planktonic foraminifers and calcareous nannofossil assemblages are less frequent and exhibit a greater degree of secondary alteration as compared to those of the upper unit. Nevertheless, microfossil recovery was sufficiently good to delineate a regular progression of middle to late Albian biozones. These zones indicate that the rate of sediment accumulation was high (approximately $40 \mathrm{~m} / \mathrm{Ma}$ ). This high rate of sediment accumulation is, no doubt, due to the large influx of carbonate shelf debris into the deep basin. Coarse, reworked inner-neritic benthic foraminifers and other material occur admixed with the autochthonous bathyal foraminiferal assemblages throughout this interval, especially below Core 540-61 (Sliter and Premoli Silva, this volume).

The greatest amount of reworked carbonate shelf debris at Site 540 occurs in the lower lithologic unit (Cores 540-77 through 540-79). Reworked and displaced shallow-water benthic foraminifers are common in this interval. These are generally mixed with abundant shallow water molluscan and echinoderm skeletal debris, particularly in the less argillaceous beds. These shallow water elements are the predominant grain type in the skeletal limestones that are interbedded with laminated limestones in this unit. The limestones are well indurated, and thin sections were necessary for planktonic foraminiferal study. Calcareous nannofossil assemblages recovered were sparse and poorly preserved. Both microfossil groups indicate an early Albian age for this unit.

The Lower Cretaceous of Site 535 has been divided into four lithologic units: (a) an upper $250 \mathrm{~m}$ unit of laminated lime mudstones with common coarse laminae of reworked shallow-water carbonate debris; (b) about $20 \mathrm{~m}$ of poorly recovered, cyclic, laminated limestones, dark marly limestones, and light, massive, ammonitebearing limestones; (c) approximately $220 \mathrm{~m}$ of light laminated limestones cyclically alternating with dark limestones and/or marly limestones; and (d) approximately $100 \mathrm{~m}$ of cyclically alternating light, bioturbated limestone and dark limestone and marly limestone. As with the sediments at Site 540, the lighter limestones typical- 
ly have poor calcareous microfossil preservation. More abundant and better preserved assemblages were recovered from the dark marly limestones and, to a lesser extent, from the dark limestones.

The biostratigraphic age assignment of the upper unit of the Lower Cretaceous sequence in Hole 535 has been the most troublesome, and certainly the most controversial, problem of any encountered on Leg 77. This unit, which includes the sediment from 535-17, CC through 535-42-4, yields somewhat different age assignments depending upon which fossil group is considered. Sparse, small, globigeriniform planktonic foraminifers were washed from some argillaceous and less indurated partings in the limestones of this unit. These forms indicated lower and middle Albian foraminiferal zones. Although the foraminiferal succession found is normal for the lower and middle Albian, the rarity and small size of the recovered microfossils, as well as some size grading that was noted, suggest that the faunas may be reworked (Premoli Silva and McNulty, this volume). This hypothesis is strengthened by the fact that coarse skeletal laminae within this sequence yield a wide variety of displaced and reworked shallow-water grains (Sliter and Premoli Silva, this volume). Calcareous nannofossil assemblages from this unit are very sparse and poorly preserved. Based upon these poor microfloras, the entire unit would be assigned to the early to middle Albian (Watkins and Bowdler, this volume). Dinoflagellate cyst preservation in this unit is apparently better than that for the calcareous microplankton fossils. Rich and diverse dinocyst assemblages from this interval are suggestive of an Albian age, with dinocyst biohorizons occurring in a more or less normal succession that spans most of the Albian (Riley and Fenton, this volume). Thus, these three microplankton groups are more or less in agreement as to the Albian age assignment of this irterval. This assignment, however, is not consistent with that based upon ammonites.

The ammonites recovered from this unit are few and juvenile. They include two specimens of Acompsoceras from the middle of the unit (Cores 535-31 and 535-33) that indicate middle Cenomanian or younger (Young, this volume). In addition, two nodules recovered from just below the base of this unit contain specimens of Scaphites, Stomohamites, and an indeterminant lytocerid that indicates late Albian or younger (Young, this volume). Because of the poor and rubbly recovery in the cores taken from immediately below the base of the upper unit, it is believed that the two ammonite-bearing nodules probably came from uphole, at some level above $535-43$, CC. Even if this is the case, the base of the upper unit can be no older than late Albian. Thus, ammonites indicate that the age of the upper unit is late Albian (at the base) to middle Cenomanian, whereas the three microplankton fossil groups suggest early Albian (at the base) to late(?) Albian.

Because of the certainty in the identification of the specimens of Acompsoceras (especially the specimen from Sample 535-31-1, 84-86 cm; see Young, this volume), that part of the unit must be middle Cenomanian or younger. Thus, the microfossils must be reworked. This is not too difficult to believe based upon the nature of the sediment. The cross-laminated nature of some portions of this interval, the size grading of some of the laminations, the coarse skeletal laminae composed of reworked carbonate shelf debris, and the presence of displaced shallow water benthic foraminifers in some samples all indicate that significant sediment transport was occurring during the deposition of most of the unit. The microfossils in question are all within the size fraction that was undergoing transport. It is likely, therefore, that the microplankton fossils were being reworked downslope. The regular progression of dinoflagellate and planktonic foraminiferal biohorizons, in their correct stratigraphic order, is more difficult to explain in this context. This is one point of the reworking hypothesis that has not yet been wholly resolved.

Below Core 535-42, the lithofacies change to cyclically alternating light laminated and/or bioturbated limestones and dark limestones and/or marly limestones. These pelagic deposits continue, with some variation, to the base of the hole. Section 535-43-3 (partim) through Core 535-46 contain strata representing at least four planktonic foraminiferal zones. This condensed section is the only Aptian recovered at Site 535 .

The remaining interval from Hole 535 (Cores 535-47 through 535-79) is a nearly complete, but not necessarily continuous, sequence of pelagic sediments that represent the late Berriasian through the early Barremian. Rare, small planktonic and benthic foraminifers were recovered from Cores 535-47 through 535-65. These occur as recrystallized specimens in thin sections from limestones and as pyritized forms in washed residues from the softer, dark marly limestones. Similarly, recrystallized or pyritized radiolarians are common and conspicuous in this interval. The planktonic foraminifers are long-ranging globigeriniform types with little age-diagnostic value. Age assignment of this interval is dependent on calcareous nannofossils (Watkins and Bowdler, this volume) and palynomorphs (Riley and Fenton, this volume). Dark, organic carbon-rich, marly limestones were preferentially examined for both palynomorphs and calcareous nannofossils. These beds yielded diverse, well preserved assemblages of both microplankton groups. Calpionellids first occur in Core 535-65 and continue down through Core 535-79 (TD). In general, calcareous nannofossils and calpionellids (where present) yield similar age assignments, whereas the palynomorphs suggest slightly older assignments. This apparent discrepancy may be due to the lack of reliable biohorizons in European sections (see Riley and Fenton, this volume). There is general agreement, however, as to the placement of the Berriasian/Valanginian boundary and that the base of the hole $(535-79, \mathrm{CC})$ contains microplankton that are late Berriasian.

\section{SUMMARY AND CONCLUSIONS}

Biostratigraphic dating and paleoecological analysis of the Leg 77 material provide a framework from which the geologic history of this part of the Gulf of Mexico 
can be reconstructed. Some of the major points resulting from this paleontological analysis, and the conclusions that may be drawn from them, are outlined below.

Pre-Cretaceous. No sediments definitively older than the Cretaceous were recovered on Leg 77 . The advanced state of diagenesis in the dolomite at the base of the section at Site 536 suggests a pre-Cretaceous age, however this sediment could not be dated by paleonotological means. The arkosic sediments at the base of the sedimentary sequence in Hole 537 may be as old as the Late Jurassic, although they are more likely Early Cretaceous. The thick sequence of sedimentary rocks lying stratigraphically below the upper Berriasian at the base of Hole 535 should include a significant thickness of preCretaceous strata. This sequence, when drilled, should reveal much information on the earlier Mesozoic history of the Gulf.

Berriasian to Aptian. The earliest Cretaceous record recovered is probably contained in the arkosic sandstones and marginal marine sediments from the base of Hole 537. The top of the basement block on which Site 537 is located must have been at or near the surface of the Gulf at this time. Both of the other basement sites (536 and 538) probably also emerged (or, at least, were near the surface) at this time, as marine Valanginian sediment lies directly upon these pre-Cretaceous rocks. By the Valanginian, all three of the basement sites were submergent. During this time, major influxes of shallow water debris occurred on the western side of the study area (basement sites). Some of this material was being reworked from exposed Berriasian and Jurassic platform sediments, whereas some of the material was contemporaneous with sediments being deposited at the basement sites (Sliter and Premoli Silva, this volume). This pulse of major reworking is not evident on the eastern side of the study area (basin sites), although some contemporaneous downslope transport of platform material apparently occurred. Some in situ accumulation of outer platform carbonates may have occurred on two of the basement sites (Site 537 and 538), although the very poor core recovery makes this difficult to ascertain. If in situ carbonate platform material is present at these sites, then they must have been within the photic zone during the Valanginian. The Hauterivian and Barremian are only questionably represented at the basement sites. Aside from a thin chalk bed at Site 537, the Aptian is represented by a thick accumulation of carbonate shelf debris at Site 536. The presence of interbedded pelagic limestones and the sedimentologic nature of the skeletal limestones indicate that this site was below the photic zone in the Aptian, and that the carbonate shelf debris accumulated as talus at the base of the Campeche platform. This type of sedimentation apparently continued into the Albian at Site 536.

The sedimentologic record of the Berriasian through Aptian of the basin sites was recovered only at Site 535 . Here, a thick sequence of cyclically alternating light and dark limestones and marly limestones spans the late Berriasian through early Barremian. The sediment record is nearly complete but not necessarily continuous. Downslope transport of carbonate shelf debris was a significant and consistent feature in what was predominantly a pelagic sedimentary environment. The cyclic nature of the sediment indicates periodic sediment anoxia, a feature common to many Lower Cretaceous bathyal sediments. The Aptian at Site 535 occurs in a poorly recovered interval, so that statements regarding its stratigraphic continuity are based upon incomplete evidence. The biostratigraphic diversity in the zones recovered, however, suggests that this thin section is probably condensed. If this is true, then sedimentation in the Aptian was distinctly different from that of the Neocomian below (with a thick pelagic section) and the Albian-Cenomanian above (with thick sections containing reworked carbonate platform debris).

Albian to Cenomanian. This time period is only poorly represented at the basement sites. A thin, but somewhat complex, sequence of upper Albian pelagic deposits overlying a thin oolitic and skeletal limestone (BerriasianValanginian) occurs at Site 538. This somewhat unusual stratigraphic and temporal association may be explained either by the rapid drowning of Catoche Knoll before the late Albian or, more likely, by the reworking (perhaps from local sources) of the shallow water carbonate unit before the deposition of the pelagic sequence. Coarse skeletal limestones of late Albian age are found at Site 536. These are almost certainly the same type of platform talus deposits that were deposited during the Aptian at this site.

The Albian through Cenomanian of the basin sites is much thicker and more pelagic in nature than at the basement sites. At basin Site 540 , more than 440 m of sediment of this age was recovered. This interval spans the early Albian through middle Cenomanian, although the majority is Albian. Although the sequence could be classified as pelagic, it has a very significant component of fine-grained carbonate platform debris. This is also true of the thick sequence of Site 535, although the age relationships are uncertain. If the microfossil age assignments at Site 535 are correct, then the thick sequences of pelagic limestones with significant finegrained platform debris at both sites are of the same age. If, however, the ammonite age assignments for the sediments at Site 535 are correct, then those sediments would be somewhat younger than the sequence at Site 540. In either case, it is clear that a significant part of the Albian through Cenomanian basin fill was derived from large influxes of fine-grained debris from nearby carbonate platforms. Much of this material was probably transported into the deep basin as distal turbidites. In spite of the correlation problems between the two basin sites, the pebbly mudstones at Site 540 are probably the youngest Cenomanian material at the basin sites. These gravity flow deposits signal a profound change in the nature of deposition in this part of the deep Gulf of Mexico. The long, nearly completely, pelagic carbonate sequence of the lower Cenomanian and Lower Cretaceous gives way to the discontinuous, often turbiditic, poorly represented middle Cenomanian through Maestrichtian. The nature of the change in oceanographic conditions that led to this radical change in depositional history is as yet uncertain, although the cessation in the in- 
flux of carbonate debris from nearby platforms into the deep basin, no doubt, figures prominently in the explanation.

Turonian to Maestrichtian. Very little record of this time period was recovered during the Leg 77. Aside from some thin volcanogenic and/or turbiditic sediments of Maestrichtian age, the only record that survives is a thin, markedly condensed sequence of pelagic sediments from Site 538. Low surface productivity is suggested by this lack of pelagic, biogenic sediment. The considerable reworking of Santonian microfossils into the Campanian at Site 538, as well as the generally poor nature of the record, suggests significant bottom current activity during the Late Cretaceous.

Paleogene. An almost complete sequence of lower Paleocene sediments occurs at Site 536. Otherwise, the early Paleocene is not represented in the Leg 77 material. The late Paleocene is better represented, with material of that age occurring at one basin site (540) and two basement sites (536 and 537). Almost all of the Eocene is represented in the Leg 77 material, although the record is scattered among several sites. Significant siliceous biogenic sedimentation occurred during the early and middle Eocene, giving rise to cherty sediments that are probably genetically similar to those of Horizon A in the North Atlantic. Significant slumping, probably related to local tectonic activity, is also quite evident in the Eocene record from Leg 77. Slumping is also evident, although not quite as well expressed, in the overlying Oligocene. The Oligocene is, by far, the best repre- sented of all of the Cenozoic epochs in the Leg 77 material. Thick sections of calcareous pelagic sediments occur at one basin site (540) and one basement site (538). These thick sections indicate a higher level of surface productivity. In addition, blooms or braarudosphaerids and, to a lesser extent, holococcoliths probably indicate periods of unusual (restricted?) surface conditions during the Oligocene.

Neogene. The Neogene sedimentary history is largely one of sediment starvation and low surface productivity. Only thin, unconformity-bound beds of calcareous ooze and chalk occur at both the basin and basement sites. Although no part of the Neogene is particularly well represented, the early Miocene and early Pleistocene are not represented by sediment at all. This indicates that the factors leading to the poor Neogene sedimentary record, such as low surface productivity, clastic sediment starvation, and (perhaps) bottom current activity, must have been particularly intense during those times.

Quaternary. In general, the Quaternary is only represented by thin beds of calcareous ooze of late Pleistocene to Holocene age. The one significant exception occurs at Site 535 , where approximately $155 \mathrm{~m}$ of distal turbidite muds were penetrated. These muds indicate a substantial influx of terrigenous clastic material derived from the Mississippi cone system.

Date of Initial Receipt: October 10, 1983 Date of Acceptance: November 1, 1983 